\title{
LIBERAL THOUGHT IN QUR'ANIC STUDIES: Tracing Humanistic Approach to Sacred Text in Islamic Scholarship
}

\section{Nur Kholis Setiawan}

UIN Sunan Kalijaga Yogyakarta, Fellow 2006-2007 of Europa im Nahe Osten der Nahe Osten in Europa, Wissenschaftskollege zu Berlin, Germany

\begin{abstract}
Literary approach to the Qur'an developed by al-Khuli created deep critiques from its opponents, in whose opinion, the usage of literary paradigm to the study of the Qur'an, according to them, implied a consequence of treating the Qur'an as a buman text which clearly indicates a strong influence of a liberal mode of thinking that goes out of the line of the Qur'an's spirit. This article shows a diametric fact compared to that they have claimed. The data proves that linguistic aspects of the Qur'an have succeeded in making an intellectual connection among progressive and liberal scholars in the classical and modern era. This supports the assumption that progressive and liberal thought whose one of its indicators is freedom of thought in accordance to Charles Kurzman term, is "children" of the Islamic civilization. Freedom of thought in the classical Islamic scholarship should be the élan of intellectualism including the field of Qur'anic studies.
\end{abstract}

Keywords: literary approach, liberal thought, Qur'anic studies, classical Islamic scholarship 


\section{A. Introduction}

The present article is inspired by a statement given by Amin alKhǖi (d. 1966), an Egyptian Qur'anic scholar who advocated using the most modern linguistic methods to approach the Qur'an with all accessible scientific methods "irrespective of religious considerations". ${ }^{1}$ His aim was to retrieve the original meaning of the Qur'anic text and how it was understood by the time it was first revealed. He asserted that the acceptance of the Qur'an, and hence of Islam by the Arabs, were based on the recognition of its absolute supremacy to any human texts, and then on the basis of evaluating the Qur'an as a literary text with its linguistic peculiarities. The linguistic aspect of the Qur'an as a point of departure of treating its literary character should be taken as a priority, and therefore, it supersedes any other religio-theological, philosophical and judicial aspects of the Qur'an. ${ }^{2}$

The ideas of Amin al-Khüli are then developed further by his pupils. ${ }^{3}$ It is Nașr Abū Zayd (b. 1942) who is eminently successful in approaching the Qur'an as a literary text. He explains that the historicity of the Qur'an as a text does not and should not mean that it is a human text. As the Qur'an is the revelation and/or manifestation of God's words at a specific time and place, it should follow that what was revealed to Muhammad in the seventh century is a historical text. This historical text is the subject of understanding and interpretation that has been done by many scholars in various schools of thought in Islamic history, whereas God's words exist in a sphere beyond any human knowledge. Therefore, socio-historical analysis is needed for understanding the Qur'an, and a very modern linguistic methodology

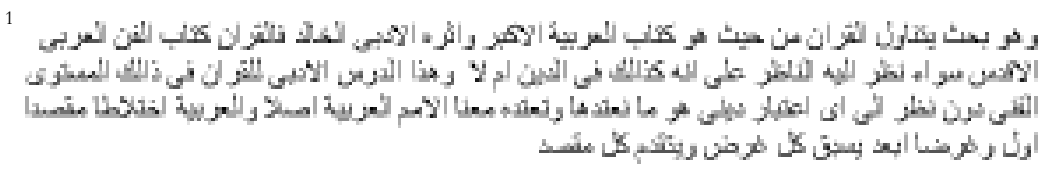

See, Amin al-KhūTi, Manāhij Tajdid fi l-Nahw wa l-Balägha wa l-Tafïir wa l-Adab, first edition, Cairo, 1961, 304.

2 Ibid, 97-98; 124-125.

${ }^{3}$ His pupils are Muhammad Ahmad Khalafallāh (d. 1997), Aisha Abd alRahmān bint al-Shāti' (d. 2000), and Nasr Abū Zayd (b. 1942). See, Nur Kholis Setiawan, "Die Literarische Koraninterpretation: Eine Analyse ihrer Frühen Elemente und ihrer Entwicklung", Ph.D. Thesis, Bonn 2003, 3-18. 
should be applied for its interpretation.

Abū Zayd has developed a general theoretical model of communication. For him, the Qur'an like any other messages, be it signs that are verbal or non verbal, presuppose a communicative The communication theory which approaches the Qur'an with a literary method developed by Abū Zayd creates a serious debate and objection among scholars. Several arguments against Abū Zayd's theory can be summarized as follows. Firstly, a literary text is a composition of human imagination while the Qur'an represents the word of God that should not be compared to any human discourse. Secondly, to deal with the Qur'an as a work of literary art is to suggest that it is written by Muhammad. Thirdly, more insulting to the Qur'an from the point of view of the traditional dogma is to claim that its language and structure is historically determined and culturally formed would easily be interpreted to mean that the Qur'an is a human text. ${ }^{4}$

Literary paradigm which belongs to humanities, according to opponents of $A b \bar{u}$ Zayd ideas, is not applicable to be used in the sacred text. It is close to liberal thought that originated in a secular mode of though that closely linked to critical Biblical studies. ${ }^{5}$ The objections of ideas of al-Khū $\bar{i}$ and Abu Zayd refer to a deep conclusion that a humanistic approach to the sacred text is not possible. Furthermore, it will lead to a humanization of a sacred religious text. With regard to the objection and the conclusion that those ideas are considered liberal, the question raised in the present article is whether Amin al-Khüli's ideas have a basis in the classical Islamic discourse and in what form those ideas are supported. How does classical scholarship strengthen liberal mode of thinking especially in the field of Qur'anic studies. The present article focuses then more on elements of approaching the Qur'an in the classical Islamic scholarship rather than discussing alKhūTi and Abū Zayd's ideas and their opponents. Particular attention will be paid to progressive notions within the framework of

${ }^{4}$ Haddad, Contemporary Islam and the Challenge of History, New York: SUNI Press 1982, 75-78.

5 Though Biblical studies use contemporary theories and philosophy of language, opponents of Abu Zaid's ideas did not mention sources to be consulted in their writings. 
hermeneutic exercise to the Qur'an whose progressiveness represents one aspect of the so called liberal in the context of Islamic thought. ${ }^{6}$

\section{B. Linguistic Aspects of the Qur'an in Classical Muslim Scholarship}

I argue here that studying linguistic aspects of the Qur'an is very important. They relate to the status of the Qur'an according to Islamic scholarship as a divine text that is inimitable, literally eternal in its Arabic linguistic form. Muslim scholars have been attracted to this field for a long time. The linguistic aspects of the Qur'an were studied carefully, some classical studies came very close to approaching the Qur'an as a textual corpus even in the earliest tafsir traditions. Examples are the works of Ibn Jurayj (d. 150/767), Muqātil ibn Sulaymān (d. 150/767), ${ }^{7}$ al-Kisā̄i (d. 189/805), Abū Ziyād al-Farrā' (d. 210/825), Ibn Qutayba (d. 276/889) $)^{8}$ et cetera.

The beginning of a comprehensive Qur'anic interpretation was made in the first part of the second century of Hijra. The creativity of scholars, who experienced the life of the Prophet, played a significant role then. According to a narrative, important exegetes in the first generation were a group of ten scholars, among whom the first were four Caliphs, al-Khulafä' al-Räshidūn. Ali ibn Abi Tâlib stood in the foreground because of his outstanding creativity in interpreting the Qur'an. The six remaining scholars were Ubay ibn Ka b (d. 23/643), 'Abdullah ibn Mas ùd (d. 32/652), Abū Mūsā al-Ash'āàri (d. 50/670), 'Abdullāh ibn 'Abbās (d. 68/686), Zayd ibn Thabit (d. 45/665), and 'Abdullāh ibn Zubayr (d. 94/712).

The Qur'anic interpretation experienced a rapid development in which the creativity of Ibn 'Abbās and his pupils had played a significant role. They often brought forth $r a^{\prime} y$, reason, to be applied in Qur'anic

${ }^{6}$ This based on Kurzman's definition of the term liberal in Islam. See, Kurzman (ed.), Liberal Islam: A Source Book, Oxford: Oxford University Press 1998, p. 4.

7 Muqātil Ibn Sulaimān, al-Asybāh wa-l-Nazāäirfi l-Qur'ān al-Karim, (ed). Mahmud Syihata, Cairo, 1975.

${ }^{8}$ Ibn Qutayba, Ta'wil Musykil al-Qur'an, (ed), Sayyid Ahmad Saqar, Cairo 1973.

9 al-Suyūti, al-Itqān fi Ulüm al-Qur'ān, I, 204-205; al-Dhahabi, al-Tafsir wa-lMufassirün, I, 63. 
interpretation. Mujāhid ibn Jabbār (d. 104/722) was one of the most knowledgeable pupils of Ibn 'Abbās, who applied this method. His work is often perceived as the beginning of the metaphorical interpretation of anthropomorphistic expressions, which was developed later by the Mu'tazilite. ${ }^{10}$ The most important pupils of Ibn 'Abbās in the Qur'anic interpretation, apart from Mujāhid, were Sa id ibn Jubayr (d. 95/713), 'Ikrima (d. 105/723), al-Ḍahhāk ibn Muzim (d. 105/ 723) and Atā' ibn Abi Rabbāh (d. 114/732). The interpretations of these scholars ranged from eschatological, historical and legal explanations to many explanations of philological nature, which one could call "word per word" interpretation. The Qur'anic interpretation of Ibn 'Abbās can be understood as the first attempt to explain the Qur'an philologically or research on Qur'anic words which is further developed by his pupils such as Mujāhid, 'Ikrima, Sa'id ibn Jubayr, Qatāda, al-Ḍahāk. Some scholars, who had analyzed the works of Ibn 'Abbās, thought that Ibn 'Abbās used pre-Islamic poetry as a source to explain difficult words which he encountered while interpreting the Qur'an. ${ }^{11}$

In the period of Ibn 'Abbās and his pupils most Qur'an exegetes interpret verses of the Qur'an "word for word" with the intention to understand the Qur'an within itself. The most common words used to designate such an interpretation is "the part of the Qur'an explains each other". One of the scholars, who applied this principle, was Muqātil ibn Sulaymān. In his work ibn Sulaymān gives a special explanation of a close connection among verses in the Qur'an. In so doing he used the expressions wa buwa ka qawlibi, or wa buwa mithlu qawlibi. This, for instance, can be seen from his interpretation of verse 28:78 wa-là yus'alu 'an dhunübibimu'l-mujrimūn, "and the wicked are not called to account for their sin". Ibn Sulaymān says, this verse is located in connection with verse 55:41: yu'rafu'l-mujrimüna bi-simäbum, "for the sinners will be recognized by their marks". ${ }^{12}$ Another example is in the

\footnotetext{
${ }^{10}$ Goldziher, Die Richtungen der Islamischen Koranauslegung, Leiden, E.J. Brill 1970, $107-110$

${ }^{11}$ Sezgin, Geschichte.., I, 26.

${ }^{12}$ Muqātil, Tafsir, II, 490.
} 
work of Sufyān al-Thawri (d.161/777). It delivers the report of 'Abdallāh ibn Mas'ūd, who made an interpretation of verse 2:28: kaifa takfurüna billähi wa-kuntum amwätan fa-abyäkum thumma yumitukum thumma yubyikum, " how can you reject the faith in God, seeing that you were without life and He gave you life, then He will cause you to die and again bring you to life". Sufyān said, this verse is similar to verse 40:11: "our Lord, you made us twice alive twice die". ${ }^{13}$

There is no doubt that Ibn 'Abbās' effort to interpret the Qur'an literarily had got attention only from scholars in Islamic religious discourse, particularly in the theological argument after the establishment of the Kharijite as Ali's opponents post-Siffin incident. Ibn 'Abbās was the envoy of 'Ali ibn Abi Tălib, the one who had special task to prove the correctness of 'Ali's thought and the falsehood of that of Khawärij. Consequently, while interpreting the Qur'an, Ibn 'Abbās made an ideological interpretation to lay his ideology on the strong basis of the Qur'an. In this case, Ali ibn Abi Talib forbade Ibn Abbās to argue with the Kharijite by using the Qur'an. This is because 'Ali believed that the Qur'an is multi interpretable, dhü wnjūh. He asked Ibn 'Abbās to argue with them by using the excessive quantity of sunnab instead. ${ }^{14}$ This phenomenon, if it truly happened, shows the oldest consciousness of the multi interpretable dimensions of the Qur'an. At least Ibn 'Abbās, the father of exegetes, could be one of the models of those who had such consciousness. The refusal of Ibn Abbās in relation to the reading, qiräah, of verse 2:137: "fa-in ämanū bi-mithli mà ämantum bibi fa-qad ibtadaw" (if they believe, the same as you believe, are quite led them), is to be understood in connection with the ta'wil of the Qur'an. Ibn 'Abbas reacted, "does not say at all, if they believe, as believed you, then are quite-led her, because it does not resemble similarity or personification of Allah. But says, if they believe, what you in God believed, then they are quite led". "bi-mithli amantum bihì',says Ibn 'Abbās, stands bil-ladhi amantum bibì... ". ${ }^{15}$

${ }^{13}$ Sufyān al-Thawri, Tafsir al-Qur'ān al-Karim, (ed.), Imtiyāz AГi Arshi, Hindustan, Wizārat al-Ma ārif li Hukūmat al-Hind 1965, 3-4.

${ }^{14}$ See, Abū Zayd, al-Ittijāh al-'Aqli fi-l-Tafsir, Diräsa fi Qadiyat al-Majāz 'ind alMu'tazila, Cairo: al-Markaz al-Thaqafi al- Arabi 1997, 96.

${ }^{15}$ al-Tabarì, Jāmi al-Bayān fi Tafsì Ayi l-Qur'àn, iii, 110 
This refusal is taken up by al-Tabari (d. 923). The comparison, which exists in this verse is like the statement, "Umar runs beside your brother, as I runs", marra "umar bi akbika mithla mà marartu bibi, ya'ni marra "umar mithla murüri bih. The comparison is drawn between the two running, not between 'Umar and the speaker. ${ }^{16}$

Mujāhid (d. 104/722), as one of Ibn 'Abbās's pupils, also followed such a trend in interpreting verses of the Qur'an. This can be seen, for example, from his interpretation of verse 2:65: wa-laqad 'alimtum alladina'tadau minkum fi's-sabti faqulnà labum kūnù qiradatan khäsitin, "and well you knew these amongst you who transgressed in the matter of the Sabbath, We said to them: 'be ye apes, despised and rejected". To the sentence "künü qiradatan khäsi in (be ye despised apes) Mujāhid says: "it was not transformed into apes, this verse is a parable like the one that is used also by God in verse 62:5: "the similitude of those who were charged (with the obligations of) the Mosaic Law, but who subsequently failed in those, is that of a donkey which carried huge tomes but understands them not". Mujāhid made an interpretation, which goes beyond the lexical border of the word. His effort to explain the Qur'an from its linguistic perspective can be regarded as a proof for his consciousness of the literary character of the Qur'an. Another example of this way of interpretation is on verse 78:27: "innabum kanū là yarjüna hisäban". The word yarjüna which means originally "hope", according to Mujāhid, can be transform into "have a fear". The semantic border between "hope" and "fear" is clear, there is no semantic relationship between the two. If Mujahid understood this word in a broader sense, it means that he made an interpretation which went beyond the lexical boundaries of the interpreted word. In the context of this verse, the interpretation of Mujāhid is directed to explain that everyone who does not believe will not have any fear of the Day of Judgment. ${ }^{17}$

The understanding of the word mathal and its derivative, which is often mentioned in the Qur'an, is important to be studied in relation to word per word explanation. One of its derivatives is tamthil a

\footnotetext{
${ }^{16}$ Ibid, 113-114

${ }^{17}$ Mujahid, Tafsir Mujähid, 324.
} 
subspecies of the literary range in Arabic language, and sometimes it is also regarded as a metaphor, maja a. Islamic scholars in this period such as Mujāhid ibn Jabr (d. 104/722), al-Hasan al-Bașri (d. 110/728), Atā' ibn Abỉ Rabbāh (d. 114/732), Qatāda (d. 128/745), al-Suddi alKabir (d. 128/745), and the next period such as Ibn Jurayj (d.150/ 767), Muqātil ibn Sulaymān (d. 150/767), Sufyān al-Thawrì (d. 161/ 777), Abū 'Ubayda al-Muthanna (d. 210/825), and Yahyā ibn Ziyād al-Farrā' (d. 207/822) regarded the word mathal as literary element of Arabic literary theory like any other such as kinaya, "metonymie" tashbih, "allegorie", and isti'ara, metaphor. ${ }^{18}$ These scholars consciously believed that the Qur'an is a "text". A remarkable fact of their consciousness can be traced from their interpretation of verses of the Qur'an by applying Arabic aspect as their primary tool of analysis.

They were of the opinion that language consists of two closely integrated levels. These two levels in modern linguistic theory became key element in the theory of meaning. They are "syntagma"19, meaning tarkib or structure as inevitable aspect of a sentence in a language and paradigma, ${ }^{20}$ dalala, as a further element of language. In the field of modern linguistics the two levels are "dynamic" aspects of the language, which cannot be separated. It means that both "syntax" and "paradigm" have an important role in formulating sentence, especially literary sentence. A meaning of a sentence cannot be understood, without

${ }^{18}$ See, Nasr Abū Zayd, al-Ittijāh al-A qli fi-l-Tafsir, Diräsa fi Qadiyat al-Majāz ind alMu tazila, Cairo, al-Markaz al-Thaqafi al- Arabi 1996, 93-100.

${ }^{19}$ This word originates from Greek language and means "bild up". In this case it goes around the vertical concatenation from single characters to a complicated unit, be it a short phrase or complete sentences. The linguistic element is by relations, which can have within a Syntagmas to other sentence elements, designation and characterized. See Karen J. Sparck, Synonym and semantic Classification, Edinburgh, Edinburgh University Press 1986; Laurence Urdang, The Basic Book of Synonyms and Antonyms, 10. Bearb. Aufl. New York 1986.

${ }^{20} \mathrm{~A}$ paradigm designates a class of words, which one can exchange among themselves. It is called also a horizontal character. In this connection it is important, under which criteria indication can be exchanged, and under which circumstances this is not possible. As example is a sentence, a dog barks; a dog bites; a dog winselt; a dog "speak". Here this expression makes no sense semantically, although it is grammatically quite correct. See, Karen, Synonym and semantic Classification, Edinburgh 1986. 56. 
considering these two aspects. The meaning lies not only on the vocabulary, but in the structure in which the vocabulary is used.

\section{Structural, stylistic and semantic aspects of the Qur'an}

\section{a. Structural aspect}

Scholarly activities on linguistic aspects of the Qur'an in the classical era are focused at least on three major fields, being microstructure, stylistics and semantics. Micro-structure is meant here as an instrument to discuss the meaning of the Qur'an through its structural point of view within the sentence or verse. Exactly the same with the structural aspect is the stylistic angle of the meaning of the Qur'an. It is to be regarded not as branch of the bare discipline of the stylistics, on the contrary, it is a starting point to work out the meaning of the Qur'an with the help of stylistic characteristic. The semantic aspect as another mechanism is considered only as a tool to analyze of the Qur'anic vocabularies, whereby the numerous classical works on Qur'anic studies show some references on its semantic analysis, and not as a subject of discussion over the different directions of semantic fields. Scholarly works on structural, stylistic, and semantic aspect of the meaning of the Qur'an are works, which are based predominantly on the three axles. Among others these are the works entitled ma'ani'qur'an, and the works entitled al-wujüh wa'-naza'ir.

The works on ma'ani'-qur'an have been very important for the development of the linguistic study of the Qur'an due to their richness of analysis regarding the language of the Qur'an. They touched upon different kinds of structures in Qur'anic expressions and its characteristics. These works are not only concerned with the structure within a sentence, but also with the possible derivative of the words, which leads to a change of meaning. Ma'anin works are relevant because these works do not only concern themselves with the meaning but also with the possible derived meanings, which are dependent on the context and structure.

The elements of the micro-structural meaning are in this sense grammatical terms which were used by grammarian and scholars on Qur'anic studies. These terms include among others al-ha:f, "ellipsis", 
al-taqdim wal-ta'kbir, "hysteron and proteron", al-nafy, "negation", and others. The Ma'anil-Qur'an works, ${ }^{21}$ particularly of al-Farra’' (d. 210/ 825), were regarded by many Muslim scholars as the perfection of the work of Abū Ubayda entitled Majāz al-Qur'an, because they discussed special forms and syntax of the Qur'an, taräkibl wa'li'räb. The name ma'ani'-qur'an of al-Farrā' is not the first name used in the discourse of the Islamic scholarship. Al-Zubaydi (d. 365/975) enumerated in his Tabaqa $\bar{t}^{2}$ a number of scholars on Arabic language and literature of the first half of the third century, which occupied themselves with the study of ma'an'll-qur'an. The first is Hamzah al-Kisāis (d. 189/ 805); followed Nadr ibn Shumayl (d. 203/818); Abū Ziyād al-Farrā', (d. 210/825); al-Akhfāsh (d. 215/830); and al-Zajjaj (d. 311/923).

The study of ma'ani was started by al-Kisāis. He is one of the great scholars who concerned themselves with the language of the Qur'an in connection to criticism of Arabic literature. The importance of his writing is underlined by the fact that Sibawaih (d. 180/976), who is a great linguist in Basra, followed al-Kisâr's thought frequently. ${ }^{23}$ The Ma'ani'l-Qur'an of al-Kisā̄i focuses mainly on three aspects: i) language, al-lugha; ii) grammar, al-nabw; and iii) art of reciting, al-qirä'a. Al-Kisā̄i analyzed the ellipsis in verse 2:234, "if any of you die and leave widows behind, they shall wait concerning themselves four months and ten days". According to al-Kisā̄i, the ellipsis, al-hårf, lies the phrase "to wait", yatarabbasna. The abbreviated phrase is its object, namely azwajabunna, "their spouse". The completed sentence is thus, "they shall wait concerning their coming spouse four months and ten days". The same case can be found in verse 9:107-108, wa'-ladina ittakhadhü masjidan diräran wa-kufran.... la taqum fibi abadan, "those who put up a mosque by way of mischief and infidelity, to disunite the

${ }^{21}$ The number of works on ma ani-l-qur'an until the fifth of Islamic calendar according to Muslim scholars are varried. Ibn Nadim mentioned 26 Works. See, Ibn Nadim, al-Fibrist I, 34. Meanwhile İsā Shihāta, the editor of al-Kisā's's Ma äni-l-Qur'ān mentioned only 18. See, al-Kisā̄r, Ma āni-l-Qur'ān, (ed.). Îsā Shihāta, Cairo, Dār alQubā' li-1-Tibā a wa-l-Nashr 1998, 2-3.

${ }^{22}$ Al-Zubaydi, Tabaqāt al-Nabwiyyin wa-l-Lughawiyyin, (ed.), Muhammad Fadl Ibrāhìm, Cairo, Muhammad Samī Amìn al-Khānji 1954, 16.

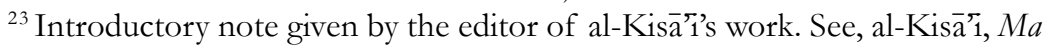
äni-l-l-Qur'àn, 4 
believers... never stand forth therein". He concentrate on the phrase never stand forth therein". According to al-Kisās 1 this phrase is clear and simple without need to mention a complete phrase as a sentence, never stand forth in the mosque which is built by those who do not really in the right path as mentioned in the verses. This structure leads to a certain extent to the opinion the economic principle of the expression, al-ijä̌r, which was developed later by al-Jāhiz (d. 255/868).

The hermeneutical approach of al-Kisāa 1 on those verses contains the referral to so-called consciousness in the modern used term of the Structuralism, particularly within the range of the literary language as other type of the language except the natural ones. If we follow for example the thoughts of the Soviet linguist and Semioticist Jurij Lotman, whereby he differentiates between the language on three general levels, i.e. i) natural speeches (e.g. Russian, English, German); ii) artistic or literary language, languages of science (meta languages of scientific descriptions or arranged signals; and iii) secondary languages, i.e. communication structures, which are established over the level of natural speeches, the language of the Qur'an goes beyond those level. It can be said that within Muslim perspective the language of the Qur'an is a supra-natural language. ${ }^{24}$ This does not mean that the Qur'anic text could not be studied scientifically, on the contrary, it provoked many scholars to study it. That has resulted numerous works on Qur'an exegesis.

In the work on ma'ani'l-qur'an, al-Farrā' (d. 210/825), ${ }^{25}$ a pupil of al-Kisā'i took over the leading role in this discussion. ${ }^{26}$ His ma 'ani' l-qur'an examines a number of aspects that deal with stylistic peculiarities in the Qur'an. His discussions go beyond philological aspect. Terms such as hysteron and proteron, ellipsis, are common in al-Farrā's work. Compared to Abū 'Ubayda (d. 276/889) al-Farrā' goes further in using some terminus technicus which are later on popularly

${ }^{24}$ See. Jurij Lotman, Die Struktur literarischerTexte, (trnsl). Rolf-Dietrich Keil, München, Wilhelm Fink Verlag 1972, 22; Die Analyse des poetischen Textes, (trnsl), Rainer Grübe, Kronberg, Scriptor Verlag 1975, 31-32.

${ }^{25}$ His name is Abū Zakariyya Yahyā ibn Ziyād (d. 207/822). For his biography see Encyclopaedia of Islam, vol. II, 806-807.

${ }^{26}$ Ibn al-Nadim, al-Fibrisat, 53. 
acknowledged by Arab literary critics. Al-Farrāa does not use majāz terms, like Abu 'Ubayda did in his work entitled Majāz al-Qur'an, but al-Farrā' employs a derivative word, namely tajawnuz, especially when he interprets verse 2:16: fa-mā rabihat tijäratubum "its trade does not bring a profit". This sentence, according to al-Farrä, goes beyond the normal forms of Arabic structure, because it is not so that the trade brings a profit, on the contrary it is the dealer, who receives a profit from his trade. This way of speech comes from everyday Arab, in which one can say, "your sales wins" or "your sales loses", rabiha bay"uka wakhasira bay"uka. Therefore, this expression is not only applicable to traders, but also to trade itself. The sentence, "their trade does not bring a profit" is thus literarily acceptable, because the reader knows, what this expression really means. ${ }^{27} \mathrm{~A}$ similar case can be found in verse 47:21: fa-idhā azama'-amru, "if the thing becomes serious". The original meaning of the verb, azama, "intend" is here as intended thing used in the sense of "the thing intends". ${ }^{28}$

Another topic of al-Farrā's discussion on the micro structural characteristic of the Qur'an is the ellipsis, al-ha:f. An example is found in verse 2:60 idrib bi 'asäka'l-hajara fa'n-fajarat minhuthnata 'ashrata 'ayna, "strike the rock with your staff. Then gushed forth from there twelve springs". The original sentence would be "then strikes Moses at rock with his staff, and twelve sources emerge", fa-daraba müsa fa'nfajarat. What is meant by the sentence is that the emergence of twelve springs is the outcome of Moses' strike. Ellipse in this context becomes an aspect which relates to the economic principle of expression of the Qur'an. Al-Farrā' is of the opinion that the ellipsis as a part of the micro structure aspect of the Qur'an is an element of its beautiful. AlFarrā's argument is not only based on Qur'anic verse such as 56:22, but also on daily language expression. It is commonly acceptable that one says: "someone got money, then he built a house, a servant, clothes, and others". The object "servant", "clothes" and others" do not stand in normal use in relation to the verb "build", but to the word "buy". At the same time hiding the verb "buy" is meant to shorten the expression,

\footnotetext{
${ }^{27}$ al-Farrā', Ma äni l-Qur'àn, I, 45

${ }^{28}$ al-Farrā', ibid, I, 14-15.
} 
so that the sentence does not become long. ${ }^{29}$

The discussions of al-Farrā' and other scholars, such as al-Kisā̄â, al-Akhfash ${ }^{30}$ and al-Zajjaj ${ }^{31}$ on the micro structure of the Qur'an show the effort to discuss the meaning of the Qur'an philologically. This effort is simultaneously an attempt to elucidate the eloquence of the sentence structurally, a term which is later on used by al-Jurjāni (d.471/ 1079). These thoughts are continued to be developed by other scholars. One of them is the Sunni theologian and linguist Ibn Qutayba (d. 276/ 898), who analyzes the eloquence of the Qur'an not only by looking at its micro structural aspects but also at its style and semantics. Ibn Qutayba's attention on the micro structural aspects of the Qur'an can be seen from his particular analysis on ellipsis, al-ba\&f, and particle of question, al-istifhàm. His discussion on ellipsis covers eight different kinds. ${ }^{32}$ The difference between ibn Qutayba's analysis on the micro structural aspect of the Qur'an with that of previous ma'anil-qur'an scholars, like al-Kisā̄i, al-Farrā', al-Akhfash and al-Zajjaj lies in the fact that ibn Qutayba's approach is clearer. The reason for this is that the method ibn Qutayba used did not follow the mushaf order of the verses. He compiled all verses that contained ellipsis and then analyzed them in accordance to their peculiar structure.

\section{b. Stylistic aspect}

The discussion on stylistic aspects of the Qur'an here will not deal with different aspects and developments of the stylistic field. Scholars on language treated stylistics as a science which takes the principle of selecting words combining these in a sentence to build an

${ }^{29}$ al-Farrā', Ma àni l-Qur'àn, II, 14. Khanji 1990

${ }^{30}$ al-Akhfash, Ma'àni-l-Qur'àn, (ed.), Huda Mahmud Qarāá, Cairo, Maktabat al-

${ }^{31}$ al-Zajjàj, Ma'äni-l-Qur'àn wa I'rabubu, (ed), Abd al-JaFil Abduh Shalabi, Beirut, 'Alam al-Kutub 1988.

${ }^{32}$ Ibn Qutayba, Ta'mil Mushkil l-Qur'ān, 162-179. 
appropriate meaning. ${ }^{33}$ Through a systematic description of the linguistic elements and their relations to one another and a description of the characteristics of natural speech language theory linguistics supplies the basis for the analysis of the stylistic use of linguistic elements. As such a discipline, the stylistic differs from rhetoric and the poetic, although their object is the same. While rhetoric examines texts regarding their effect on the person spoken to, the stylistic regards texts particularly as a sign of a character, and the poetic lies on the emphasis of an investigation on possibilities of finding and of inventing new kinds and types of signs which are possibly not yet being used. What is important for writing style as used in the Qur'an, however, is the fact that the Qur'an, according to Arab scholars, exhibits special characteristics, which other texts do not have. The eloquence and most beauty of the Qur'anic expression are to be understood within the dogma of the "inimitability" (ijaz) of the Qur'an.

Meaning theory in classical Muslim scholarship is on the one hand a starting point for studying the Arab language theory in general, and then, its basis of the literary discourse. On the other hand, however, it is also related to the argument on the status of the Qur'an as a text. The Arabic term ma'ani covers a number of aspects: lexical, syntactic and stylistic. ${ }^{34}$ In the context of ma'ani discourse the statement of alJāhiz (d. 255/868) has a great importance. ${ }^{35}$ He says with reference to an anonymous source:

${ }^{33}$ There are some sources that deal with the concept of stylistics. Among others F. Eberhard, Text und Stilrezeption; empirische Grundlage zur Stilistik, Königstein, Althenaeum 1980; F. Wolfgang, Name und Text; ausgewählte Studien zur Onomastik und Stilistik, Tübingen, Niemeyer 1992; F. Norbert, Stilistik, Narrativik, Metaphorik: Neure Textbeschreibungsmodelle in ibrer Anwendbarkeit auf amerikanische Prosa, Heidelberg, Winter 1995

${ }^{34}$ See, al-Ferrani, Die Ma nā Theorie bei Abd al-Qähir al-Jurjāni (d. 471/1079) Versuch einer Analyse der poetischen Sprache, Frankfurt am Main, Peter Lang 1990, 41-42

${ }^{35}$ Al-Jāhiz's ideas on arabic literary theory and criticism were the object of some research. Among others Mishal Asi, Mafähim al-Jamäliyya wa-l-Naqd fi Adab al-Jähiz, Beirut, Dār al- Ilm li-l-Malāyin 1974; Idrìs Bilmalih, al-Ru'ya al-Bayāniyya ind al-jahiz, alDār al-Baydā', Dār al-Taqāfa 1984; Fawzì al-Sayyid, al-Maqāyis al-Balāghiyya ind al-jabiz fil-Bayān wa-l-Tabyìn, Beirut, Dār al-Thaqāfa 1983; al-Shāhid al-Būshìki, Mustalabāt Naqdìyya wa Baläghiyya fi Kitāb al-Bayān wa-l-Tabyin li-l-Jähiæ, Beirut, Dār al-Afāq 1982 
ma' 'ani are in the human heart, they form in its understanding, move in its soul, connect themselves with its spirit and develop from its thinking. They are euphemistically, secretly, far, isolated, hidden, exist in the sense of the non existentness (ma'nā ma düma). Only by others, human beings can recognize needs and aids of his partner and companion. ${ }^{36}$

This passage indicates that meaning can only be recognized through a medium that could be a language, be it oral or written, or through a code in modern semiotic terms. ${ }^{37}$ Al-Jạhiz enumerates five forms of the code; i) word, lafa, ii) indication or sign, ishära, iii) convention, 'aqd, iv) condition, hăal and v) phenomenon, nisba. ${ }^{38}$ It can also be inferred from al-Jāhiz's statement that he gives a dynamic connection between "meaning" (dalala) and communication. "The importance of the code which is emphasized by al-Jahiz in the process of communication reminds us of modern communication theory as advocated by Jurij Lotman ${ }^{40}$ or Michel Foucault. ${ }^{41}$

The ma'na theory by al-Jāị has a partly theological background due to his effort to show that the Qur'an is inimitable. He furthermore states that "inimitability" of the Qur'an can be traced in at least three aspects from the language point of view: i) "word meaning" (daläla); ii) word selection; and iii) "economization" of expression.

Al-Jāhiż's discussion on the language of the Qur'an started with analyzing the verse in Sure 2:31: wa-'allama ädam'l-asmä'a kullahā, "Allah

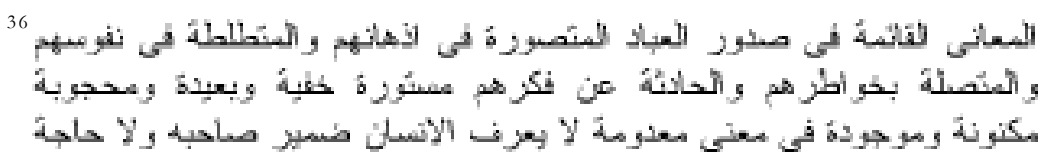

al-Bayān wa-l-Tabyin, I, 42.

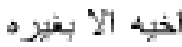

${ }^{37}$ See, modern discourse on semiotics for instance by Jurij Lotman Die Analyse des poetischen Texte, 1975; idem, Die Struktur literarischer Texte, 1972.

${ }^{38}$ Al-Jāhiz, al-Bayān wa-l-Tabyin I, 43-44; al-Hayawān I, 33-35; 45-46.

${ }^{39}$ Al-Hayawä I, 211.

${ }^{40}$ Jurij Lotman, Die Struktur literarischer Texte, (transl)., Rolf-Dietrich Keil, München, Wilhelm Fink Verlag 1972; idem, Die Analyse des poetischen Textes, (trnsl.), Rainer Grübel, Kronberg, Scriptor Verlag 1975.

${ }^{41}$ Michel Foucault, The Archaeology of Knowledge and the Discourse on Language, 1982, 24-25; H. Dreyfus \& P. Robinson, (eds.), Michel Foucault; Beyond Structuralism and Hermeneutics, Chicago, Chicago University Press 1983, 45. 
has taught Adam all names". Al-Jạhiz commented that it is impossible that God has taught Adam only the names without their meanings. This is justified by the fact that a word without meaning would be something senseless. The relationship between word and meaning is as between bodies and spirit. The word is the body of the meaning and the meaning the spirit of the word. If God had given only the words to Adam, without sense, would be like a man, who would have given another something senseless. ${ }^{42}$

Another aspect that is theologically justified is the Qur'anic vocabulary. Al-Jâhiz compares the vocabulary of the Qur'an with vocabularies in classical arabic poetry. He comes to the conclusion that only the Qur'an — and not the Arab poetry, let alone normal Arab people - fully express all nuances of the Arab vocabulary. ${ }^{43}$ According to al-Jăhiz, the difference between Arabic poetry and the Qur'an lies in the fact that poets use words as synonym, which in reality do not have the sam meaning. Two Arab words for "rains", ghayth and matar both were used by the poets frequently synonym. It is only in the Qur'an that these two words are found in the appropriate context. One can interpret that al-Jạhiz differentiates the two words in their connotative meanings depending on their usage in a context, although they have the same denotative meaning.

The Qur'an always uses the word al-matar, according to al-Jāhiz, in connection with punishment or revenge. ${ }^{44}$ This nuance is ignored by poets. The first example hereof is written in verse 4:102: wa-la junāha alaykum in kāna bikum adhan min matarin aw kuntum marda an tadha $\bar{u}$ aslihatakum (and it is not a passing for you, if you are suffered from rain or are ill, to put down your weapons). And secondly is in verse 46:24: fa-lammā ra'awhu àridhan mustaqbila awdiyatibim qālū bādh $\bar{a}$ àridhun

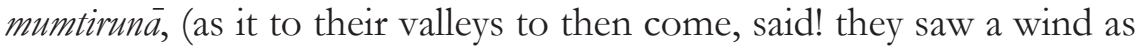
drawing up: That is a drawing up wind, which will bring us rains). This verse concerns people of Hüd who perceived the rain as mercy of

\footnotetext{
${ }^{42}$ Al-Jāhiz, Al-Hayawān, V, 201-202.

${ }^{43}$ al- arabu rubbamā istakhaffat aqalla-l-lughatayni wa-ad afabumā, wa-tasta milu mà huwa aqalla fi asli-l-lugha isti mālan wa-tada u mā huwa aẓhara wa-akthara". Al-Jāhiz, al-Bayān wa-l-Tabyin I, 20

${ }^{44}$ Al-Bayān wa l-Tabyin, I, 20.
} 
God, rahma. However, this verse is in fact meant as punishment, which is expressed in the following verse, bal huwa mästa jaltum bihi rïhun fih à adhäbun alim tudammiru kullu shay'in bi amri rabbihä, "no! (one answered to them). That is that, with which their so hasty had it: a wind, which holds a painful punishment".

A second example is the use of saghab and $j \bar{c}$, both lexically mean "hungry". Contrary to the word saghab, the word $j \vec{u}$ as used in the Qur'an is always found in the meaning of a punishment or a negative connotation, as for example 16:112... fa-'adhāqahà llābu libās al-jū' wa'l-khawfi bi-mà kānū yasna'ün, "Allah made it taste of hunger and terror because of the evil which (its people) wrought". Meanwhile, the word saghab does not always stand in the context of negative connotations, as exemplified in verse 90:14 aw it'amun fi yawmin dbi masghaba, " or the giving of food in a day of privation". ${ }^{45}$

The third aspect discussed by al-Jạiz is the economic expression. Concise expressions are to a certain extent an economic principle of an expression, which in the modern discourse can also be regarded as an aspect of the beauty of the literary language. The so-called economics principle in the sense of modern discourse means that languages serve their communicative purpose with the simplest way. By the economics principle, al-ijāa, al-Jāhiz indicates the eloquence of the language of the Qur'an. The most remarkable example of such short expressions is found in verse 56:19: là yusadda'inna anbā wa-là yunzifün, "with a beverage, of which it cause neither headache nor become drunk". Al-Jāhiz has the opinion that this verse entails a praise over nature and quality of wine in the heaven which is so very different from that on earth. The information of the Qur'an on earthy wine is extensive, but the description of wine in "heaven" is brief and the meaning is clear. Al-Jạhiz states that the short sentence on the wine in heaven indicates it is celestial and has positive effect, while, the long and detail account of wine on earth indicates its lesser quality. ${ }^{46}$

${ }^{45}$ Lam yudhkar al-jū illā fi mawāqi i-l-iqāb aw fi mawāqi i-l-faqri al-mudqi wa-l-ajzi alzăhir. Al-Jāhiz, al-Bayān wa-l-Tabyīn I, 20.

${ }^{46}$ Al-Jāhiz, al-Hayawān, III, 86; V, 430-431; and Rasāîl al-Jāhiz, III, 43. 
A similar view is accomplished by the Qur'an scholar and Sunni theologian Ibn Qutayba (d. 276/898), whereby he advocates that verse 79:30 is the most representative example of the principle of the "economics expression". Although Ibn Qutayba and al-Jạhiz differ in their way of elucidation, both do have the same opinion. When discussing verse 79:30 and its comprehensive meaning, both come to the conclusion that the Qur'an contains the principle of the economic expressions.

\section{c. Semantic aspect}

Semantics is difficult to define. The term "semantics" is systematically ambiguous. It refers both to a certain aspect of the linguistic research (one speaks e.g. of the semantics of a word), and to theory or science of meaning. ${ }^{47}$ An often accepted hypothesis on semantics is the distinction between "primary" or basic meaning and "relational meaning". Primary meaning of a word is the meaning always associated to a word, no matter where it is used. "Relational meaning "is connotative and the meaning thus depends on the context. Each individual word, when it is taken separately from a sentence, has its own fundamental meaning. The vocabulary of the Qur'an is not an exception to this. For this, the word kitäb $b^{48}$ is an example. Firstly, it means "book". In the context of the Qur'an, this word holds further connotative meanings, like "Qur'an", "revelation", scripture of the Jews and Christianity" as long as the context of the Qur'an is concerned.

This study will not deal with the different ranges of semantics. However, many classical works on the Qur'an entitled al-wujūh wa'-

${ }^{47}$ Detailed discussion about semantics, see, R. Reichart, Aufklärung und historische Semantik; interdiziplinäre Beiträge zur westeuropäischen Kulturgeschicbte, Berlin, Duncker und Humbolt 1998; G. Fritz, Historische Semantik, Stuttgart, Metzler 1998; Ingo Radatz, Die Semantik der Adjektivstellung; eine kognitive Studie zur Konstruktion "Adjektiv", Tübingen, Niemeyer 2001.

${ }^{48}$ See, Madigan, The Qur'an's Self-Image: Writing and Authority in Islam's Scripture, Princeton, Princeton University Press 2001. 
naza"i ${ }^{49}$ show a "semantic consciousness" as an attempt at elucidating various meaning of Qur'anic vocabularies. The word wajh, "meaning nuance", as a term ${ }^{50}$ for the possible "derived meaning" is to be deduced first of all from the statements of A $\mathrm{A}$ ibn Abi Tálib (d. 42/662). It is narrated that Ibn Abi Țalib assigned ibn Abbās to reject the religious argument of the Khärijite not to base this arguments on the Qur'an, on the contrary on the Sunna. The Qur'an is accordingly ambiguous, and ibn Abi Țalib is narrated to say as following: 'argue against them not with the Qur'an, because the Qur'an is ambiguous', wa-là tujādilhum bil-qur'ni fa-innabu bammälu dhi wujūbin ".51

The word wujüh as part of the linguistic discussion of the Arabs, was used for example in a work of Abū Bakr al-Anbari (d. 328/940), ${ }^{52}$ in his book entitled Kitāb al-Addàd. The "didd" designates ambiguity of a word in which it occurs often in the Qur'an. Muslim scholars used the word wajh in relation to the word nazäir as an expression al-wujüh wa'-naza'-'ir. The ambiguity of words in the Qur'an was underlined by many Muslim scholars. One of them is Ibn Sa'd, who delivers a report of Abū Darda', “you do not know the Qur'an completely until you could recognize exactly its ambiguous character", là tafqabu ḥattā tarā al-qur'āna wijühan. ${ }^{53}$

The beginning of the so called "semantic consciousness" in the Qur'an exegesis is historically very much tied Muqātil ibn Sulaymān (d. 150/767). The Qur' an exegesis of Mujāhid ibn Jabbār (d.100/

${ }^{49}$ The works entitled al-Wujūh wa l-Nazä'ir since the era of Muqāil ibn Sulaymān until the middle of the fifth century are among others ibn Sulaymān, al-Ashbāh wa lNazāìr, (ed.). Mahmūd M. Shihāta, Cairo, al-Hay'a al-Misriyya al- Âmma li 1-Kitāb 1975; Yahyā ibn Salām, al-Tasārif; Tafsir al-Qur'àn min-mā ishtabahat Asmäuh wa-Tatarrafat Ma ānìb; al-Hākim al-Tirmidhi, Tabsìl Nazāìir al-Qur'ān, (ed.), Husnī Nasr Zaydān, Cairo 1970; al-Tha alabi, al-Ashbäh wa l-Nazä'ir fi l-Alfäz al-Qur'äniyya allatì Tarädafat Mabānīhà wa-Tanawwa at Ma änīhä, (ed.), Muhammad al-Masri, Damascus, Sa'dudin li-1'Tiba'a wa-l-Nashr 1984.

${ }^{50}$ More detail about the discussion of the term and its roots, how it is used in Arabic literature and its development, see. Salwā Muhammad Awwāl, al-Wujūh wa-lNazǟir fi-l-Qur'ān al-Karim, Cairo, Dār al-Shurūq 1998, 40-47.

${ }^{51}$ al-Suyūti, al-Itqān, I, 141.

${ }^{52}$ About ibn Sa'd, see The Encyclopaedia of Islam, I, 485.

${ }^{53}$ Ibn Sa'd, Tabaqät ibn Sa'd, 2/2, 114. 
718) precedes ibn Sulaimān's one, but Mujāhid's tafsir pays, however, less attention to the semantic aspect. The relevant works of ibn

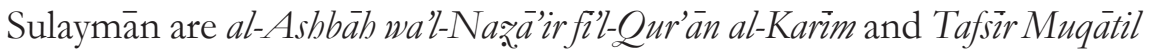
ibn Sulaymān. ${ }^{54}$

Ibn Sulaymān attributed a certain and limited sense to each word, and regards possible deviating meanings as its derivatives. As an example is the word mawt that originally means "death". This word, according to Ibn Sulaymān, has four derived meanings, namely i) which was not aroused yet to the life; ii) human beings who have wrong faith; iii) dry soil; and iv) lost spirit. First of all ibn Sulaymān confirm the original meaning of mawt. In his opinion the word mawt means "death" in the sense of a total death. Such a meaning can be understood from the verse 39:30, "truly you will (one day) die, and they will (one day) die", and also in verse 3:185, "every soul shall have a taste of death; and only on the Day of Judgment shall you paid your full recompense". Ibn Sulaymān emphasizes that every Qur'anic word only has one basic meaning, then it has possible derivative or alternative meanings. He also states that someone could not be considered as a real master, when he or she does not recognize the possible faces of the Qur'an self. $^{55}$

Another remarkable interpretation of ibn Sulaymān that refers to the relationship between the original and derived meaning of a word, is his explanation about the word $m \bar{a}$, "water". According to him, the word $m \vec{a}$ ' has three derived meanings. First of all, it could mean "rain", matar, such as in verses $15: 22 ; 25: 48 ; 8: 11$; and 31:10. One of these verses reads "and we send the fecundating winds, then cause the rain to descend from the sky, there with providing you with water (in abundance)" (15: 22). Secondly, it could also mean sperm, al-nutfa, such as in verse 25:54, "It is He who created human being from water, then has He established relationship of lineage and marriage..."; 32:8: "and made his progeny from a quintessense of the nature of a fluid despised". And thirdly, the word mä' could also mean something needed as a basis for the life of believers, such as in verse 16:65 "And God

${ }^{54}$ Edited by Abdullāh Mahmūd Shihāta, Cairo, al-Hay'a al-Misriyya al- Âmma li-1-Kitāb 1985.

${ }^{55}$ Abū Zayd, al-Ittijāh al- Aq $i \ldots . ., 98$ 
sends down rain from the skies and gives there with life to the earth after its death, verily in this is a sign for those who listen" ${ }^{156}$ In this verse the word is regarded by ibn Sulaymān as a metaphor. ${ }^{57}$ This assumption is also emphasized by other scholars such as al-Jāhiz (d. 255/868), Ibn Qutayba (d. 276/898) and Abd al-Qāhir al-Jurjānì (d. 471/1079).

Further elaboration of the semantic awareness of the Qur'an is carried out by Hārūn ibn Mūsā (d. 170/786) in his book entitled alWujūh wa'-Naşä'ir fi'l-Qur'an al-Karim. ${ }^{58} \mathrm{He}$ insists that the word wujüh is meant a derived meaning of word apart from its primary one. Besides vocabulary that influences meaning there are structure and stylistics as factors which have a significant role in creating meaning. The same endeavor had been done by al-Jāhiz. His works such as al-Bayān wa'Tabyìn, al-Hayawàn, Rasä̀il al-Jähì. al-Bukhalà and others indicate his semantic awareness of the Qur'an.

In his Rasā'il al-Jāhiz analyzes several Qur'anic verses that could be seen as examples of tracing the alternative meaning apart from its basic one. One of them is nafkh al-ruh, "soul breath" in verses 4:171; 21:92; 66:12; 32:9. The Qur' an uses this word in different contexts, which can affect the so-called "semantic area" in al-Jạhiz’s term. First the Qur'ān uses this word in verse 4:171 "and his word, which He bestowed on Mary, and a spirit proceeding from him". Second, in verse 66:12 fa-nafakhnā fibi min rühinā, "and We breathed into (her body) of Our spirit", and 32:9 wa-nafakba fibi min rühibi, "and breathed into him something of his spirit", exactly the same is also to be found in verse

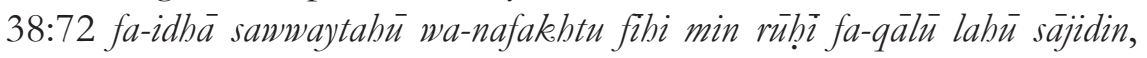
"when I have fashioned him (in due proportion) and breathed into him of my spirit, fall ye down in obeisance unto him)". According to alJạhiz, the word rūh originally means "soul", and also "spirit of God", if this word is set in connection with the pronoun "God", i.e. rübubu or rühibi in the context of speaking of God. In addition, this word could also mean the Qur'an, particularly in the context of verse 42:52 wa-

\footnotetext{
${ }^{56}$ Ibid, 221

${ }^{57}$ Ibid, $180-181$.

${ }^{58}$ Edited by Hātim Sālih al-Dāmin, Bagdad, Wizārat al-Thaqāfa wa-l-A'lām 1988.
} 
kadhälika awḩaynà ilaykea rühan min amrinā, "and thus have We, by Our command (logos), sent inspiration to you"; 70:4 tanazalul-malä'ikatu wa'r-rüu, "the angels and the spirit rise (on the sky leaders) to him". Although the two words in verses 42:52 and 70:42 as have been understood by most Qur'an exegetes, nevertheless, this word according to al-Jāhiz still mean the "Qur'an", because the "spirit" in the context of both verses is not a bare spirit, on the contrary it implies the "internal aspect" of revelation, i.e. the spirit of God. ${ }^{59}$

A similar argument has been proposed by Ibn Qutayba. His work entitled Ta'wil Mushkill al-Qur'än partially discusses this aspect under the column "deviating meaning of a word from its original sense", mukhälafah zăhir al -lafi. ma'nābu. ${ }^{60}$ This column treats not only words, but syntax, whereby the context plays a role again. Ibn Qutayba's discussion on the different kinds of contexts, which influence the deviation of meaning, is not so explicit. His analysis treats the deviating meaning of part of a sentence, such a question word, al-istifhàm, whereby it originally concerns a question. However, this istifham often changes itself, to a statement, al-taqrir, ${ }^{61}$ or an appeal, whereby it originally designates an "instruction ", then changes itself to an option, al-ibahha $a{ }^{62}$ which belongs in the modern discourse of the Arab language theory to the range of the discipline al-ma'ani wa'l-bayan.

Among the deviating meaning of a word, as it is being regarded by Ibn Qutayba, is a word kufr, disregard, kaffir, ${ }^{63}$ unbeliever, qawl, ${ }^{64}$ speech, nisyan, forgetting, hasana and sayyi'a, property and bad ones. These words, although Ibn Qutayba does not mention them directly as "deviating meaning of its original sense", because they belong to different column in ibn Qutayba's work, nevertheless, these words partially belong in the modern discourse on the so-called meaning

${ }^{59}$ al-Jahiz, Rasāìl al-Jāhiæ, (ed.) Abd al-Salām Hārūn, Beirūt, Dār al-Jil 1991, vol. III, 347-349.

${ }^{60}$ Ibn Qutayba, Ta'will Mushkil al-Qur'ān, (ed.), Sayyid Ahmad Saqar, Cairo, Dār Ihyā' al-Kutub al- Arabiyya, 213-229.

${ }^{61}$ Ibn Qutayba, Ta'mỉl, 215.

${ }^{62}$ Ibid, 216

${ }^{63}$ Ibid, 54.

${ }^{64} \mathrm{Ibid}, 78-84$ 
nuance of a word, or in the classical Arab literature science concerning the literary tendency of the Qur'an exegetes to "al-wnjūh wa'l-nazääir".

\section{Elements of Liberal Thoughts in Muslim scholarship}

"Liberal Islam may sound like a contradiction in terms," says Charles Kurzman. ${ }^{65}$ This statement is based on Western scholarship's identification to Islam and Islamic world for centuries. Islamic faith is equated with fanaticism, meanwhile Islamic tradition is regarded as backwardness and primitiveness, Islamic political authority is perceived to be a despotism, and Islamic military practices are regarded as terror and rape. In sum, all about Islam and Islamic world is being identified with threatening "images of theocracy and terrorism. ${ }^{66}$

It is well understood that the term "liberal" implies some modern standards that include against theocracy, promoting democracy, awareness of rights of women, rights of non-Muslims, freedom of thought and progressiveness. ${ }^{67}$ The present article has found the linkage of a progressive thought in classical scholarship on Qur'anic studies with the term used by Kurzman. It can be inferred from the elucidation on linguistic aspects of the Qur'an that scholars on Qur'anic studies in the classical era are aware of the principle of freedom of thought.

An awareness of several scholars in the early period of the multi interpretable status of the Qur'an is one indication of that principle. It is shown also that from the early development of Qur'anic studies Ibn Abbbās, the father of exegetes has used ta'wil, comparable to hermeneutics in modern term, in understanding several verses of the Qur'an. Mujāhid ibn Jabbār, one of Ibn Abbās' pupils, made interpretation of several verses of the Qur'an which goes beyond a lexical border of the word. His effort to explain the Qur'an from its linguistic perspective can be regarded as a proof for his consciousness of the literary character of the Qur'an.

Within the discourse on linguistic aspects of the Qur'an scholars in the classical era have developed theory of meaning which is

${ }^{65}$ Charles Kurzman, (ed.), Liberal Islam: A Source Book, Oxford: Oxford University Press 1998, 3.

${ }^{66} \mathrm{Ibid}, 3$.

${ }^{67}$ Ibid, 5-6. 
comparable to that of in modern era. As has been illustrated in previous paragraph several classical exegetes were of the opinion that language consists of two closely integrated levels that in modern linguistic modern theory became key element in the theory of meaning. Both are "syntagma", meaning tarkib or structure as inevitable aspect of a sentence in a language and "paradigma", dalla, as a further element of language. Both "syntagma" and "paradigma" have an important role in formulating sentence, especially literary sentence. A meaning of a sentence cannot be understood, without considering these two aspects. The meaning lies not only on the vocabulary, but in the structure in which the vocabulary is used.

This theory is used in the classical era to depict meaning of Qur'anic words. It can be inferred that taking into consideration the theory to be applicable to the Qur'an implies that the Qur'an is perceived to be a text. It is not possible to place the Qur'an as text without considering an awareness to approach it as a result of a communication between God and the Prophet in Arabic as its code. Hence, placing the Qur'an as a text, as being accused to be liberal mode of thinking by several Muslim scholars in modern era, has been existing in the classical scholarship. It is a logical way to assume that liberal thought in modern era has its root in the classical Islamic scholarship.

The notion of multi interpretability of the Qur'an can be understood as a shifting of paradigm, using Thomas Kuhn word, ${ }^{68}$ when the statement was given by $\mathrm{A} \Gamma \mathrm{ibn}$ Abi Talib, a representative of a scholar in the very beginning of the development of Qur'anic interpretation. The multi interpretability of the Qur'an implies the status of the Qur'an as text that needed to be approached with human knowledge and understanding.

The theory of meaning which is applied to depict meanings of the Qur'an was developed further by al-Jāhiz when he introduced mediums of communication that are among others word, sign, convention, condition, phenomenon and made a dynamic connection between meaning, dalala, and communication. Theory of communication developed by al-Jāhị implies to some extent a "humanization" of a religious text which is in fact liberal in nature.

\footnotetext{
${ }^{68}$ Thomas Kuhn, The Structure of Scientific Revolutions, Chicago, 1970, 15.
} 
In sum, it can be found in the classical era that Muslim scholars were closely tied with progressive ideas and even liberal in the sense of Kurzman's terminology. Liberal, progressive ideas and freedom of thought are inherent in the academic and intellectual atmosphere of Muslim scholars in the classical era. The debate on the nature of the Qur'an whether it is eternal that attached to the character of God, sifat alläh, or His creation, makblīq, is one of the indications. ${ }^{69}$ Only with a dynamic and discursive atmosphere intellectualism functions its significant role in developing community, one thing that has been shown by intellectual life in the field of Qur'anic studies in the classical era.

\section{Conclusion}

Linguistic aspects of the Qur'an have succeeded in making an intellectual connection among scholars in the classical and modern era. The ideas of al-KhūIi and Abū Zayd on approaching the Qur'an as a text have a strong basis in the classical scholarship on the Qur'an. Retrieving meanings in the Qur'an in the classical scholarship was an intellectual endeavor that employs several comparable aspects to that of studying text. Terms of linguistic studies such as structure, style, semantics et cetera are applicable to the study of the Qur'an. The Qur'an has influenced the development of Arabic theory of language and literature on one hand, on the other, those theories, which are invented, have been used by scholars to study the Qur'an. In other words there is a so called a reciprocal relationship between the Qur'an and theories of language.

Classical scholarship on the Qur'an has shown a deep intellectual endeavor that creates wide space for intellectual exercise that opens freedom of thought. Liberal thought is then a product of the Islamic civilization. It is not an exaggeration to conclude that liberal thought exists in the field of Qur'anic studies since the beginning of its development. This implies at the same time that blaming humanistic approach to study the Qur'an as a liberal mode of thought which is adopted from non-Islamic scholarship is historically unreliable.

${ }^{69}$ See for example, Abū Zayd, al-Ittijāh al-Aqli fi l-Tafsir: Dirāsa fi Qadhiyat alMajäz ind al-Mu tazila, Cairo, al-Markaz al-Thaqafi al- Arabi 1997, 34-55. 


\section{BIBLIOGRAPHY}

Abū Zayd, Nasr Hāmid, al-Ittijāh al-'Aqli fi'l-Tafsir, Dirāsa fi Qadiyat al-

Majāz 'ind al-Mu'tazila, Cairo: al-Markaz al-Thaqafi al- Arabi, 1997.

Abū Zayd \& Siza Qasim (eds), Anzimāt al-Alāmāt: Madkhal ilā Simiyutiqiyya, Cairo, 1986.

al-Akhfash, Ma'äni al-Qur'an, ed. by Huda Mahmud Qarāa, Cairo: Maktabat al-Khanjī, 1990.

Asis, Mishal, Mafābim al-Jamāliyya wa'-Naqd fi Adab al-Jāhìn, Beirut, Dār al- 'Ilm li'l-Malāyin, 1974.

Bilmalih, Idriss, al-Ru'ya al-Bayāniyya 'ind al-Jāḥi̧, al-Dār al-Bayḍā', Dār al-Thaqāfa, 1984.

al-Būshìki, al-Shāhid, Mustalaḥāt Naqdiyya wa Balāghiyya fi Kitāb al-Bayān wa'l-Tabyin lìl-Jāḅis, Beirut, Dār al-Afāa, 1982.

Dreyfus, H \& P. Robinson, (eds.), Michel Foucault; Beyond Structuralism and Hermeneutics, Chicago: Chicago University Press, 1983.

Eberhard, Frank, Text und Stilrezeption; empirische Grundlage zur Stilistik, Königstein: Althenaeum, 1980.

al-Farrā', Ma'äni l-Qur'ān, ed. by Abd al-JaFil Abduh Shalabi, Cairo, 1988.

Fawzì, al-Sayyid, al-Maqāyis al-Balāghiyya ind al-Jāḥiz fi'l-Bayān wa'lTabyin, Beirut: Dār al-Thaqāfa, 1983.

al-Ferrani, Die Ma nā Theorie bei Abd al-Qäbir al-Jurjānì (d. 471/1079)

Versuch einer Analyse der poetischen Sprache, Frankfurt am Main: Peter Lang, 1990.

Fritz, George, Historische Semantik, Stuttgart: Metzler, 1998.

Foucault, Michel, The Archaeology of Knowledge and the Discourse on Language, 1982.

Goldziher, Die Richtungen der Islamischen Koranauslegung, Leiden: E.J. Brill, 1970.

Haddad, Yvonne Yazbeck, Contemporary Islam and the Challenge of History, New York: SUNI Press, 1982. 
Ibn Qutayba, Ta'will Mushkil al-Qur'ān, ed. by Sayyid Ahmad Saqar, Cairo: Dār Ihyā' al-Kutub al- Arabiyya, 1973.

Ibn Sulaimān, Muqātil, al-Asybāh wa'l-Naz̧āir fi'l-Qur'ān al-Karim, ed. by Mahmud Syihata, Cairo, 1975.

Ibn Salm, Yahy, al-Tasrif; Tafsir al-Qur'n min-m ishtabahat Asm'uh waTatarrafat Ma'ānīh, Cairo: Dār Ihyā̄a al-Kutub al- Arabiyya, 1978. al-Jāhì, Abū Amr, Al-Hayawān, (ed.), Hārun ibn Mūsa, Cairo: alHay'a al-Misriyya al- Amma li l-Kitāb, 1976.

—, Rasāil al-Jāḥiz, (ed.) Abd al-Salām Hārūn, Beirūt: Dār al-Jil, 1991. al-Kisā̄in, Hamzah, Ma ānī-l-Qur'ān, (ed.). İsā Shihāta, Cairo: Dār alQubā' li'l-Tibā a wa'l-Nashr, 1998.

al-Khūî, Aminn, Manāhij Tajđid fi'l-Nahw wa'l-Balāgha wa'l-Tafsir wa'lAdab, first edition, Cairo, 1961

Kuhn, Thomas, The Structure of Scientific Revolutions, Chicago, 1970

Kurzman, Charles, (ed.), Liberal Islam: A Source Book, Oxford: Oxford University Press, 1998.

Lotman, Jurij, Die Struktur literarischer Texte, (trnsl). Rolf-Dietrich Keil, München: Wilhelm Fink Verlag 1972.

Madigan, Daniel, The Qur'an's Self-Image: Writing and Authority in Islam's Scripture, Princeton: Princeton University Press, 2001.

Norbert, F., Stilistik, Narrativik, Metaphorik: Neure Text-beschreibungsmodelle in ihrer Anwendbarkeit auf amerikanische Prosa, Heidelberg: Winter, 1995.

Radatz, Ingo, Die Semantik der Adjektivstellung; eine kognitive Studie zur Konstruktion "Adjektiv", Tübingen: Niemeyer, 2001.

Reichart, R., Aufklärung und bistorische Semantik,; interdiziplinäre Beiträge zur westeuropäischen Kulturgeschichte, Berlin: Duncker und Humbolt, 1998.

Salwā, Muhammad Awwāl, al-Wujūh wa'l-Nazā'ir fi'l-Qur'ān al-Karim, Cairo: Dār al-Shurūq, 1998,

Setiawan, M. Nur Kholis, "Die Literarische Koraninterpretation: Eine Analyse ihrer Frühen Elemente und ihrer Entwicklung", Ph.D. Thesis, Bonn 2003. 
Sparck, Karen J., Synonym and semantic Classification, Edinburgh: Edinburgh University Press, 1986.

al-Tirmidhi, al-Hākim, Tabsil Nazā'ir al-Qur'ān, (ed.), Husnì Nasr Zaydān, Cairo, 1970.

al-Tha'alabi, al-Ashbh wa l-Naz'ir fi l-Alfã al-Qur'niyya allati Tardafat

Mabnīhā wa-Tanawwa at Ma'ānīh, (ed.), Muhammad al-Masri,

Damascus: Sa'dudin li-l-Tiba'a wa-l-Nashr, 1984.

al-Zajjāj, Ma'äni-l-Qur'àn wa I'rabubu, (ed), Abd al-Jalil Abduh Shalabi, Beirut: 'Alam al-Kutub, 1988.

al-Zubaydi, Tabaqät al-Nabwiyyin wa-l-Lughawiyyin, (ed.), Muhammad Fadl Ibrāhim, Cairo: Muhammad Samì Aminn al-Khānjī, 1954.

Wolfgang, F., Name und Text; ausgewäblte Studien zur Onomastik. und Stilistik, Tübingen: Niemeyer, 1992. 